Stanistaw Chrobak*

Warszawa

\title{
Kultura aktywnego obywatelstwa racją życia społecznego
}

Swoistość bycia i stawania się człowieka wyraża się między innymi tym, że nie jest on kimś raz określonym, dokonanym, zrealizowanym i zamkniętym. W stawaniu się, w które zaangażowana jest całość egzystencji, szczególne znaczenie ma podmiotowo-osobowe bycie i aktywność. Aktywność człowieka w przestrzeniach jego możliwości stawania się między dziedzictwem genetycznym i socjokulturowym środowiskiem a własną podmiotowością osobową jest dla każdej jednostki szansą i próbą, wyzwaniem i przerażeniem, aktywnością bycia i ucieczką od życia. Bowiem życie człowieka realizuje się nie tylko w układzie ,zamkniętym” organizmu czy aktywności i dynamiki psychiki. Człowiek na sposób sobie właściwy jest otwarty i kreatywny: stający się i spełniający siebie ${ }^{1}$.

Niepokój zaś dotyczy zasadniczej i podstawowej sprawy: czy ów postęp, którego autorem i sprawcą jest człowiek, czyni życie ludzkie na ziemi pod każ-

* Ks. dr hab. Stanisław Chrobak, prof. UKSW, jest profesorem w Katedrze Historii Wychowania i Dziejów Oświaty, na Wydziale Nauk Pedagogicznych Uniwersytetu Kardynała Stefana Wyszyńskiego w Warszawie. Adres: Wydział Nauk Pedagogicznych UKSW, ul. Wóycickiego 1/3, budynek nr 15, 01-938 Warszawa; e-mail: s.chrobak@uksw.edu.pl.

1 Por. Kazimierz Popielski, „Pytanie o człowieka”, w: Człowiek-wartości-sens. Studia z psychologii egzystencji, red. Kazimierz Popielski (Lublin: Redakcja Wydawnictw Katolickiego Uniwersytetu Lubelskiego, 1996), 16-20. 
dym względem „,bardziej ludzkim”, bardziej „godnym człowieka”? Nie można żywić wątpliwości, że pod wielu względami czyni je takim. Pytanie jednak, które uporczywie powraca, dotyczy tego co najistotniejsze: czy człowiek jako człowiek w kontekście tego postępu staje się lepszy, duchowo dojrzalszy, bardziej świadomy godności swego człowieczeństwa, bardziej odpowiedzialny, bardziej otwarty na drugich, zwłaszcza dla potrzebujących, dla słabszych, bardziej gotowy świadczyć i nieść pomoc wszystkim?²

Dynamizm rozwojowy człowieka nie jest wolny od wstrząsów, od wzlotów i upadków, konfliktów, nieporozumień, rozczarowań, poczucia szczęścia i poczucia winy. $\mathrm{W}$ toku przemian dokonujących się na przestrzeni życia zdarzenia, które stają się udziałem człowieka, wpisują się w historię jego życia, wyznaczają ważne obszary jego aktywności i zaangażowania. Poniższa refleksja ma na celu poszukiwanie odpowiedzi na pytanie, jak odpowiedzialne zaangażowanie na rzecz innych sprzyja ludzkiej formacji tych, którzy chcą się angażować i jak ich przygotować do aktywnego obywatelstwa, solidarności i spotkania osób.

\section{Odkryć własną wartość na gruncie współpracy i wspólnoty}

Relacje człowieka z innymi ludźmi są źródłem szczególnej wartości.

Współżycie z innymi ludźmi - jak stwierdza Tadeusz Tomaszewski - uczestnictwo w ich życiu i dopuszczanie innych do uczestnictwa w życiu własnym, dzielenie się z innymi własnymi przeżyciami i myślami, podejmowanie wspólnych z nimi zadań, włączenie wyników własnej działalności do dorobku ogólnego - to dla człowieka jedno z najpotężniejszych źródeł wartości³

Obok kontaktów interpersonalnych, dla kształtowania się młodego człowieka istotne pozostaje jego funkcjonowanie $\mathrm{w}$ otoczeniu zespołu ludzi uczciwie pracujących, wzajemnie życzliwych, działających wspólnotowo, a także jego kontakt ze sprawnie działającą instytucją. Uczestnictwo w grupie stymuluje rozwój samodzielności, pomysłowości, wzmacnia poczucie własnej warto-

2 Jan Paweł II, Encyklika Redemptor hominis (Rzym, 4 marca 1979) (Warszawa: Wydawnictwo Ośrodka Dokumentacji i Studiów Społecznych, 1979), 15.

3 Tadeusz Tomaszewski, Ślady $i$ wzorce (Warszawa: WSiP, 1984), 207. 
ści. Pozwala tworzyć środowisko sprzyjające kształtowaniu się współpracy, negocjowania, dyskutowania, kierowania pracą innych i poddawania się kierownictwu.

W różnorodnych relacjach działania „wspólnie z innymi” przedstawia się jako dostosowaną do tych relacji - a więc różnorodną - postać odniesienia osoby do „,innych”. Relacja ,ja-ty” ma profil między-osobowy. Ów „ty” jest ze swej strony kimś, czyli jakimś drugim , ja”. Na gruncie relacji ,,ja-ty” rośnie też odpowiedzialność osoby za osobę. W takiej relacji ,ja-ty" kształtuje się autentyczna międzyosobowa wspólnota. Spotkanie ,ja” i „ty” respektuje ich podmiotowość, transcendencję i własną dążność do samospełnienia. Pełnym zaś wyrazem potencjalności społecznej natury człowieka jest „my”. „My” wprowadza nas w świat innych ludzkich odniesień i wskazuje na wymiar społeczny ludzkiej wspólnoty. Wspólnota, tworząc sferę wspólnych potrzeb, zainteresowań i działań, zmierza do łączenia ludzi w szerokim zakresie wspólnie uznawanych wartości, wspólnie przyjętych zasad. W tej perspektywie wymiar „my” pojawia się jako konsekwencja relacji ,ja-ty”. Świat oferuje dzisiaj człowiekowi wiele możliwości. Każdy z nas może funkcjonować w kilku kontekstach społecznych i wielu sferach, które nie muszą się wykluczać. Jednak życie we wspólnej przestrzeni jest łatwiejsze i lepsze, gdy istnieją fundamenty akceptowalne przez większość. Fundamenty umożliwiające budowanie wspólnego świata, w którym ludzie dobrze się czują. Wspólnota oparta na fundamentalnych wartościach stanowi ramę odniesienia dla ludzi i zbiorowości w każdych czasach. Wartości nadają sens każdemu obszarowi i aspektowi życia ludzkiego 5 .

Kogo widzę, gdy widzę człowieka? - pyta Abraham Joshua Heschel. (...) Ów stojący przede mną, konkretny człowiek wcale nie musi być mi bliski i drogimogę go nawet darzyć niechęcią. Może być on jednak drogi i bliski dla kogoś innego, na przykład dla swojej matki, chociaż i to nie jest powodem jego wyjątkowego statusu. Nawet jeżeli nikomu na nim nie zależy, on i tak pozostaje człowiekiem ${ }^{6}$.

${ }^{4}$ Por. Karol Wojtyła, „Osoba: podmiot i wspólnota”, w: tenże, Osoba i czyn oraz inne studia antropologiczne (Lublin: Wydawnictwo Towarzystwa Naukowego KUL, 1994), 401-402, 406.

5 Por. Małgorzata Bogunia-Borowska, „Życie w dobrym społeczeństwie. Wartości jako fundament dobrego społeczeństwa", w: Fundamenty dobrego społeczeństwa. Wartości, red. Małgorzata Bogunia-Borowska (Kraków: Wydawnictwo Znak, 2015), 19-20.

${ }^{6}$ Abraham Joshua Heschel, Prositem o cud. Antologia duchowej madrości, thum. Aleksander Gomola (Poznań: W drodze, 2001), 63. 
Osoba zatem jest tego rodzaju bytem, który wnikając w rzeczywistość, wyraża siebie, samopoznaje, uświadamia się, odkrywa, rozjaśnia, doświadcza, weryfikuje. Przez te wszystkie akty i działania świat staje się na swój sposób wewnątrzosobowy, a jednocześnie osoba się uzewnętrznia i obiektywizuje. Cały sens tak zwanego doczesnego życia ludzkiego wtedy tylko zyskuje wartość, gdy to wszystko, co człowiek czyni teraz, jest tylko zapoczątkowaniem „pełni” i spełnienia się ludzkiej osoby w jej aktach osobowych. Prawdziwa wspólnota ludzka jest tam, gdzie osoba odnajduje siebie poprzez dar z siebie i zdolność przyjęcia daru drugiego człowieka. Czynnikiem o decydującym znaczeniu jest wzajemna współzależność - sytuacja, w której jednostki potrzebują siebie i są sobie nawzajem potrzebne, jeśli chcą osiągnąć swój cel7. Tym samym

nie wystarcza przechadzać się po cyfrowych „drogach”, a więc po prostu połączyć się: trzeba aby temu połączeniu towarzyszyło prawdziwe spotkanie. Współobecność zatem nie gwarantuje spotkania - aby się spotkać, trzeba zawsze dokonać wolnego, świadomego wyboru. (...) Taka otwartość konkretyzuje się w spotkaniu na nowym forum, na nowej agorze, gdzie od każdego oczekuje się, że będzie zaangażowany w szczere poszukiwanie prawdy ${ }^{8}$.

Wzrastania w wymiarze społecznym nie można ujmować jedynie jako zewnętrznej zdolności do nawiązywania kontaktów międzyludzkich. Osoba bowiem doskonali się przez uczestnictwo, które jest aktywnością, otwarciem dwustronnym: odbiorem i dawaniem. „Osoba, która zachowując swoje specyficzne cechy, nie ukrywając swojej tożsamości, angażuje się całym sercem w jakąś wspólnotę, nie rozpływa się w niej, ale otrzymuje nowe bodźce do własnego rozwoju. Nie jest to ani sfera globalna, która prowadzi do rozpłynięcia się, ani odizolowana cząstkowość, skazująca człowieka na bycie jałowym" ". Osoba jest więc określana z jednej strony przez własną aktywność, z drugiej zaś przez odpowiednie prowadzenie i oddziaływanie z zewnątrz. Odkrywa, że współdziałanie międzyludzkie jest czymś, co pozostaje ciągle do zrealizowania. Czyny, które spełnia człowiek jako członek różnych

${ }^{7}$ Por. Tadeusz Styczeń, Rozum i wiara wobec pytania: Kim jestem? (Lublin: Towarzystwo Naukowe Katolickiego Uniwersytetu Lubelskiego, 2001), 50-57.

${ }^{8}$ Francesco De Meo, „Komunikacja w służbie nauki społecznej Kościoła”, Społeczeństwo 3 (2014): 75.

9 Franciszek, Adhortacja apostolska Evangelii gaudium (24.11.2013) (Częstochowa: Edycja Świętego Pawła, 2013), 235. 
społeczności czy wspólnot, są równocześnie czynami osoby. Osoba bowiem nie może się rozwinąć i zrealizować swych potencjalności i usprawnień bez współdziałania z innymi osobami, zespołem innych osób komunikujących się we „wspólnym dobru” i stanowiących z tego powodu jakieś „my”10.

Osobista wartość osoby jest realizowana przez każdego poprzez dowartościowanie siebie, z takim bogactwem, jakie dla każdego jest możliwe, czy to w zależności od własnych zdolności, czy też zależnie od wszystkich uwarunkowań historycznych, tzn. egzystencjalnych, którym każdy osobiście podlega. Chodzi więc o powinność, która wpisuje się w całość być i móc, i która nie może w żaden sposób abstrahować od egzystencjalnej sytuacji, w jakiej znajduje się osoba, ani też od itinerarium, jakie dane jest jej przebyć w swoim doświadczeniu ${ }^{11}$.

Godność osoby ludzkiej, wspólne dobro, współpraca i solidarność to kluczowe problemy, jakie wyłaniają się z bezpośredniego zestawienia Ewangelii z konkretną sytuacją społeczną. To człowiek, budując świat, buduje jednocześnie siebie. Wspólnota tworzy przestrzeń duchową, która pozwala jednostkom zrozumieć sens ich działań i przeżyć.

Jeśli chodzi o kościół katolicki - podkreśla papież Benedykt XVI - zasadniczym celem jego wystąpień na arenie publicznej jest ochrona i uświadomienie godności osoby ludzkiej, toteż świadomie zwraca on uwagę na zasady, które nie mogą być przedmiotem negocjacji. Wśród owych zasad dziś są szczególnie ważne następujące:

- ochrona życia we wszystkich jego fazach, od chwili poczęcia aż do naturalnej śmierci;

- uznanie i propagowanie naturalnego modelu rodziny, jakim jest związek mężczyzny i kobiety oparty na małżeństwie, oraz obrona tego modelu przed próbami zrównania go w prawach z radykalnie odmiennymi rodzajami związków, które w istocie rzeczy osłabiają rodzinę i przyczyniają się do jej desta-

10 Por. Stanisław Chrobak, „Człowiek twórcą/podmiotem rozwoju - wyzwania edukacyjne w globalizującym się społeczeństwie”, w: Wychowanie i ksztatcenie w systemach politycznych, red. Elmar Anhalt, Dariusz Stępkowski (Warszawa: Wydawnictwo Salezjańskie, 2012), 159-160.

${ }^{11}$ Giusseppe Flores d'Arcais, „Propozycja personalistyczna”, w: Człowiek - Wychowanie - Kultura. Wybór tekstów, red. Franciszek Adamski (Kraków: Wydawnictwo WAM, 1993), 86-87. 
bilizacji, przysłaniając jej szczególny charakter i utrudniając postrzeganie jej niezastąpionej roli społecznej;

- ochrona prawa rodziców do wychowywania własnych dzieci.

Zasady te nie są prawdami wiary, choć oczywiście wiara jest dla nich dodatkowym oświeceniem i potwierdzeniem; są one wpisane w samą naturę człowieka, a zatem wspólne dla całej ludzkości. Działania Kościoła na rzecz krzewienia owych zasad nie mają zatem charakteru religijnego, ale dotyczą wszystkich ludzi, niezależnie od tego, jakie jest ich wyznanie. Działania te są tym bardziej konieczne, im częściej owe zasady są odrzucane bądź źle rozumiane, mamy wówczas bowiem do czynienia z podważaniem prawdy o osobie ludzkiej oraz poważnym naruszaniem samej sprawiedliwości ${ }^{12}$.

Chrześcijanie - razem z wszystkimi ludźmi dobrej woli - wezwani są do podejmowania wyzwań obecnego czasu i mają w ten sposób wskazywać kierunki i sposoby rozwiązywania najbardziej istotnych problemów współczesności. Dlatego konieczne jest zainteresowanie drugim człowiekiem, szczególnie tym, który potrzebuje pomocy, który sam nie może dać sobie rady tak w wymiarze materialnym, jak i duchowym, oraz formułowanie projektów życia o charakterze zarówno osobistym, jak i wspólnotowym.

\section{Kultura jakości życia w służbie społecznej}

Człowiek tworzy swoją historię biograficzną i dziejową. Co więcej, jest zdolny do przekraczania uwarunkowań własnej i otaczającej go rzeczywistości. Stawia sobie cele i zadania. Projektuje przyszłość, dąży do tego, by być tym, kim jeszcze nie jest, a może być. Rozwój człowieka charakteryzuje i kształtuje szczególny rodzaj doświadczeń i aktywności. Realizuje się w projektach i zatroskaniach, dążeniach i odniesieniach. Charakteryzuje się podmiotowo-osobowym życiem. Jest aktywnym i interpretującym uczestnikiem życia, a nie tylko narracjonistą, widzem czy miejscem wydarzeń życiowych.

Człowiek rodzi się i wzrasta o ile jest w relacjach. Rodzi się z relacji miłości, żyje w środowisku rodzinnym i tam się rozwija tym lepiej, w im większym

12 Benedykt XVI, „W obronie chrześcijańskiego dziedzictwa Europy. 30 III 2006 - do uczestników kongresu zorganizowanego przez Europejską Partię Ludową”, L Osservatore Romano 8 (2006): 20. 
stopniu jest to środowisko miłości. (...) W relacjach ujawnia się cała siła namiętności, uczuć, popędów emocjonalnych, artystycznych i twórczych, lęki, nadzieje, oczekiwania, plany, a także troski o sprawy polityczne, o dobro wspólne, o sprawiedliwość. (...) Nie jest bowiem możliwe, by traktować człowieka jako związanego tylko umową społeczną egoistę w stosunkach rynkowych ${ }^{13}$.

Człowiek tworzy kulturę, ale i ona kształtuje jego życie. Kultura otwiera perspektywę ludzkiego rozwoju ze względu na prawdę (wiedza), dobro (moralność), piękno (twórczość), boskość (religia). „Kultura zatem to jakaś rzeczywistość tworzona przez człowieka na drodze jego osobowych przeżyć i działań, tak jednostkowych, jak i społecznych. Stąd wszelkiego rodzaju wytwory człowieka, jako rezultat jego osobowego działania, stanowią świat kultury"14. Bez względu na to, co poszczególne dyscypliny wiążą z pojęciem kultury, najważniejszy jest sam człowiek - to, jakim jest, jakim się staje i jakim się stawać powinien w wyniku pracy nad sobą. Kultura zostaje w ten sposób usytuowana w odniesieniu do człowieka i do jego podstawowych wymogów: prawdy i wartości. Zatem sama kultura to jakaś rzeczywistość tworzona przez człowieka na drodze jego osobowych przeżyć i działań, tak jednostkowych, jak i społecznych. Kultura, tworząc zespół powiązań pomiędzy osobami żyjącymi wewnątrz każdej wspólnoty, określa międzyludzki i społeczny charakter bytu człowieka. Obejmuje zarówno formy, przez które wyrażają się lub kształtują wartości, jak też obyczaje, język, sztukę, literaturę, instytucje i struktury współżycia społecznego ${ }^{15}$.

Odbierzcie człowiekowi wszystkie jego ideały, ośmieszcie symbole, z których składa się jego świat kulturowy, przekonajcie go, że nie ma nic, na co powinien czekać, i nic, co powinien czcić, a będzie wielbić produkty otaczające go w życiu codziennym i cały swój zapał, jeżeli jest do tego zdolny, poświęci dalszemu polepszaniu tego życia. (...) Ekonomizm odnosi zwycięstwo walkowerem, bo ośmieszone zostały wszystkie wartości, które mogłyby go zwalczać albo po

13 Franco Appi, „Nowy humanizm a spójność Europy”, Społeczeństwo 1-2 (2015): 208-209.

${ }_{14}$ Mieczysław Albert Krąpiec, Człowiek w kulturze (Lublin: Redakcja Wydawnictw KUL, 1999), 35.

15 Por. Stanisław Chrobak, Podstawy pedagogiki nadziei. Wspótczesne konteksty w inspiracji personalistyczno-chrześcijańskiej (Warszawa: Wydawnictwo Uniwersytetu Kardynała Stefana Wyszyńskiego, 2009), 441-445. 
prostu zająć część oddanej mu przestrzeni. Kiedy odebrano wartość wszystkiemu, co nie rynkowe, wyłączną atmosferą egzystencji staje się rynek ${ }^{16}$.

Dynamika istnienia wspólnoty zależy od zaangażowania jednostek, które ofiarowują wspólnocie część własnego życia i duchowej energii. Im mocniej jednostka wpływa na tożsamość wspólnoty, tym bardziej się w nią angażuje i tym bardziej wspólnota zakorzenia się we wnętrzu jednostki i kształtuje jej tożsamość. „Służba społeczna jest bowiem prawdziwą szkołą humanizacji i obywatelstwa. Jest miejscem, które ożywia i wypełnia teren, buduje sieci służące spotkaniu. Jest sytuacją, w której człowiek się uczy i poświadcza, że inny świat naprawdę jest możliwy"17. Również w dzisiejszych czasach młodzi są gotowi brać na siebie część odpowiedzialności, pod warunkiem że znajdzie się ktoś, kto potraktuje ich poważnie, włączy w jakąś aktywność, pomoże im ukierunkować energię, pozwalając im żyć ze zdrową pasją dla drugiego w perspektywie wspólnoty. Młody człowiek może się sprawdzić, odkryć własne zdolności, a także znaleźć swoją drogę zaangażowania i realizacji. Zaangażowanie w wolontariat, w służbę obywatelską, w działalność na rzecz innych ludzi, na rzecz społeczeństwa, a nie tylko dla własnej korzyści, nie jest czymś oczywistym w kulturze, w której dominuje wymiar indywidualistyczny, mający skłonność do pozostawiania tych wartości na marginesie. Odnawianie wartości zwróconych w kierunku zaangażowania w działalność wolontariacką, solidarnościową i obywatelską wskazuje na wiele sytuacji wymagających różnych form bliskości, współpracy, tworzenia i wzmacniania skutecznej sieci powiązań i zasobów w lokalnych wspólnotach. „Potrzebna jest dziś - podkreśla Jan Paweł II - nowa «wyobraźnia miłosierdzia», której przejawem będzie nie tyle i nie tylko skuteczność pomocy, ale zdolność bycia bliźnim dla cierpiącego człowieka, solidaryzowania się z nim tak, aby gest pomocy nie był odczuwany jako poniżająca jałmużna, ale jako świadectwo braterskiej wspólnoty dóbr"18.

Wzajemne zaufanie, uczciwość, bezinteresowna pomoc, odpowiedzialna wolność, stałe reguły moralne itp., będące podstawowym spoiwem zdrowego społeczeństwa, rzadko rozwijają się bez jakiegoś religijnego kontekstu,

${ }^{16}$ Chantal Desol, Esej o czlowieku późnej nowoczesności, tłum. M. Kowalska (Kraków: Wydawnictwo Znak, 2003), 151.

17 Nunzio Galantino, „Wychowywać młodzież do odpowiedzialnego obywatelstwa”, Społeczeństwo 1-2 (2015): 175.

18 Jan Paweł II, List apostolski Novo millennio ineunte (06.01.2001) (Warszawa: Centrum Duszpasterstwa Archidiecezji Warszawskiej, 2001), 50. 
a człowiek nie może w pełni zrozumieć siebie samego bez Boga. Chrześcijanie mają dziś obowiązek, w łączności i w dialogu z innymi, angażować się w działania publiczne i społeczne. Kwestia obecności katolików w przestrzeni społecznej nabiera nowego znaczenia w porównaniu z tym, z czym mieliśmy do czynienia w przeszłości. Chodzi o wytworzenie nowej formy uczestnictwa i nowej obecności skupiającej się na:

- promowaniu kultury uczestnictwa, wychodzącej od terytorium i wspólnoty;

- tworzeniu albo podnoszeniu jakości uczestnictwa obywateli;

- zwiększaniu kontaktu z instytucjami i zaufania do nich, poczynając od lokalnych;

- stałym byciu blisko osób wybranych i formacji do działania;

- umacnianiu poczucia odpowiedzialności.

Jest pilną sprawą, żeby przez idee i propozycje przywrócić w naszych zmęczonych społeczeństwach „smak przyszłości” oraz konkretne, praktyczne poczucie „dobra wspólnego”, aby nie stało się ono czymś abstrakcyjnym ${ }^{19}$. Działanie praktyczne pozostaje niewystarczające, jeżeli nie jest w nim widoczna miłość do człowieka, miłość, która karmi się spotkaniem z Chrystusem. „Chrześcijańskie miłosierdzie to nie tylko altruizm i pojedyncze gesty, ale to nade wszystko troska o całokształt osoby ludzkiej. Nie wystarczy chrześcijaninowi mówić: «chcę, mogę, potrafię», lecz potrzeba o wiele głębszego: "rozumiem, chcę, potrafię i wytrwam»" ${ }^{20}$. Chrześcijanin nie rezygnuje zatem z podejmowania działania, które ma służyć jemu samemu i wspólnocie, w której żyje. Ukazując własną tożsamość, ma on służyć całej społeczności ludzkiej, a więc i tym, którzy nie podzielają wiary katolickiej.

Relacje między ludźmi są zawsze relacjami wzajemnej zależności, co przejawia się w różnym stopniu w życiu osoby, a w większej mierze staje się widoczne w kondycji starości, choroby, niesprawności, ogólnie cierpienia. A to wymaga, aby w relacjach międzyludzkich, jak również $\mathrm{w}$ relacjach wspólnotowych, świadczona była niezbędna pomoc, aby starać się odpowiedzieć na potrzebę, jaką dana osoba ujawnia w danej chwili. Społeczeństwo jest prawdziwie otwarte na życie, kiedy uznaje, że jest ono cenne również w wieku starszym, że powołanie do realizacji człowieka nie wyklucza cierpienia, co więcej, uczy postrzegania osoby chorej i cierpiącej jako daru dla

19 Por. Savino Pezzotta, „Obecność katolików w polityce”, Spoleczeństwo 5-6 (2013): $118-120$.

${ }^{20}$ Piotr Krakowiak, „Edukacyjne funkcje wolontariatu i ich percepcja w nauczaniu Kościoła w XXI wieku”, Paedagogia Christiana 2/32 (2013): 171. 
całej wspólnoty, obecności, która odwołuje się do solidarności i odpowiedzialności. Nauka i technika, oddane na służbę osoby ludzkiej i jej podstawowych praw, przyczyniają się do integralnego dobra człowieka. Młodzi ludzie dzięki służbie społecznej mogą nawiązać relacje z osobami dorosłymi, z którymi się zetknęli i które im towarzyszyły. Są to wzajemne powiązania, które wpływają na kształt paktu międzypokoleniowego. Dają możliwość rozwoju w perspektywie daru z siebie i odkrycia własnej wartości na gruncie wspólnoty i współpracy ${ }^{21}$. „Płaszczyzna egzystencjalna jest zatem podstawą konstytuowania człowieka jako człowieka, w stronę jego «górnych możliwości», w stronę pełni. Jest także punktem wyjścia ku rzeczywistości transcendentnej, ku sacrum"22.

\section{Międzypokoleniowa pamięć i spotkanie}

Człowiek tylko w relacji do innych może osiągnąć pełnię własnego człowieczeństwa i realizować siebie jako osobę. Człowiek nie może bowiem być sobą, nie otwierając się na to, co od niego inne, szczególnie na innych ludzi.

Życie ludzkie - jak stwierdza Zbigniew Zaborowski - przebiega w warunkach społecznych; na każdym kroku spotykamy ludzi, współpracujemy z nimi, funkcjonujemy w grupach, społecznościach. Problem interpersonalny jest jednym z ważniejszych problemów życiowych człowieka. Korzeniem człowieka jest drugi człowiek, spotkanie głębsze z niektórymi ludźmi kształtuje naszą osobowość i tożsamość ${ }^{23}$.

Spotkanie między ludźmi umożliwia szerokie i głębokie doświadczenie aktualnej rzeczywistości. Jest jakaś tajemnica w każdym spotkaniu z drugim człowiekiem. Każde spotkanie z drugim człowiekiem zawiera zarówno szansę, jak i zagrożenie rozwoju. Trwać może kilka minut albo wiele lat;

${ }^{21}$ Por. Franciszek, „Najcięższą chorobą, na jaką są narażone osoby starsze, jest opuszczenie. Przesłanie z okazji 20-lecia Papieskiej Akademii «Pro Vita»”, L 'Osservatore Romano 3-4 (2014): 20-21; Galantino, ,Wychowywać”, 175.

22 Jarosław Michalski, „Konstruowanie tożsamości podmiotowej w kontekście kategorii sensu w pedagogice", Paedagogia Christiana 2/32 (2013): 13-14.

${ }^{23}$ Zbigniew Zaborowski, Problemy psychologii życia (Warszawa: Oficyna Wydawnicza PROFI, 2001), 282. 
może się zapisać w pamięci na trwałe lub prędko zostać zepchnięte w niepamięć. I bywa, że jakieś spotkanie, które dawno uleciało z pamięci, dla tego drugiego stało się punktem zwrotnym w życiu. Człowiek w swoim otwarciu się, dawaniu, realizuje siebie samego. Odkrywa, że relacje międzyludzkie są zawsze aktualnym wyzwaniem ${ }^{24}$. „Właśnie dlatego - pisał Jacques Maritain - że jestem osobą i że wypowiadam się sam przed sobą, staram się komunikować z tym, co jest inne, i z innymi ludźmi, aby poznać i kochać. Dla osobowości istotne jest szukanie dialogu, i to takiego dialogu, w którym ja rzeczywiście daję siebie i w którym jestem przyjmowany"25.

Całość życia ludzkiego charakteryzują określonego typu relacje i określony spójny projekt własnego życia, na który składają się:

- osobowości poszczególnych reprezentantów pokoleń, czyli to, co każdy z nich wnosi, wraz z historią;

- rozumny wybór przyjaciół, partnerów relacji przekraczających jedno tylko pokolenie;

- koncepcja życia społecznego, budująca się powoli na bazie własnego potencjału i własnej koncepcji życia.

Wymienione aspekty zdają się czynnikami wymagającymi uwzględnienia ich w relacjach międzyludzkich, w tym międzypokoleniowych, co zostaje zapoczątkowane już w rodzinie ${ }^{26}$. Rodzina jest pierwszym i najważniejszym środowiskiem człowieka, wyjątkowym miejscem rozwoju osoby. Jej dynamizm poprzez poszczególnych jej członków oraz sąsiedztwo rzutuje na całą społeczność lokalną, narodową i ogólnoludzką. „W niej przychodzimy na świat, rozwijamy się, choć niestety nie zawsze umieramy. Jako wspólnota uczuć, rodzina jest wyjątkowym miejscem rozwoju osoby, jest pierwszą i główną przestrzenią wychowania człowieka. W jej łonie kształci się i wychowuje dzieci, które później jako obywatele będą wypełniać swoje role społeczne"27.

W rodzinie człowiek realizuje się i nieustannie odnawia. W kontakcie z innymi ludźmi i dzięki nim człowiek zdobywa wiedzę o sobie, przeży-

${ }^{24}$ Por. Elżbieta Sujak, Rozważania o ludzkim rozwoju (Kraków: Wydawnictwo Znak, 1998), 187-191.

25 Jacques Maritain, Pisma filozoficzne, tłum. Janina Fenrychowa (Kraków: Społeczny Instytut Wydawniczy Znak, 1988), 334.

${ }^{26}$ Por. Marian Nowak, „Pedagogika wzorów i pedagogika spotkania w dialogu pokoleń", w: Dialog pokoleń. Studium interdyscyplinarne, red. Kazimierz Franczak (Warszawa: Wydawnictwo Salezjańskie, 2007), 93.

${ }^{27}$ Arturo Cattaneo, „Społeczna rola rodziny”, Społeczeństwo 3 (2014): 111. 
wa poczucie własnej wartości, dokonuje się akceptacja drugiego człowieka. System wartości regulujących życie małżeńsko-rodzinne, specyfika relacji i doświadczeń wewnątrzrodzinnych, stają się motywem działań, kształtują sposób myślenia, wyzwalają energię, wyznaczają kierunek postępowania. Wpływa na całość stosunków rodzic-dziecko, a przez to - pośrednio lub bezpośrednio - na kształtowanie się osobowości młodego człowieka. W ten sposób buduje się cała złożona sieć zależności, nieustanna interakcja, która ma przemożny wpływ na sposób myślenia i wiedzę dziecka o sobie, kształtowanie się jego reakcji czy wzorców funkcjonowania, spostrzeganie świata czy innych ludzi ${ }^{28}$.

Pamięć osób starszych naszego społeczeństwa jest wsparciem w postępowaniu naprzód. Przyszłość społeczeństwa (...) jest zakorzeniona w ludziach starszych i w młodzieży - tej ostatniej, ponieważ ma siłę i wiek, pozwalające budować historię; w tamtych, ponieważ są żywą pamięcią. Lud, który nie troszczy się o osoby starsze i o dzieci oraz młodzież, nie ma przyszłości, ponieważ niszczy pamięć i obietnicęe 29 .

Sytuacje życiowe człowieka nie wyrastają tylko z jego sfery duchowej, ale także z jego biologicznego podłoża. Rodzina jest wspólnotą szczególnie intensywnych wzajemnych odniesień: pomiędzy małżonkami, pomiędzy rodzicami a dziećmi oraz między pokoleniami. Gdy rodzina nie jest zamknięta w sobie, dzieci uczą się, że każda osoba jest godna miłości oraz że wszystkich ludzi łączy podstawowe i powszechne braterstwo. Rodzina jest niezastąpioną szkołą człowieczeństwa.

Znajomość i zdolność do zajmowania stanowiska wobec wydarzeń minionych - podkreśla papież Franciszek - to jedyny sposób, aby zbudować sensowną przyszłość. Nie można wychowywać bez pamięci: „Przypomnijcie sobie dawniejsze dni" (Hbr 10, 32). Opowiadania osób starszych czynią wiele dobrego dzieciom i młodzieży, ponieważ łączą je z historią przeżytą czy to przez rodzinę, dany region czy też ojczyznę. Rodzina, która nie szanuje i nie dba o swoich dziadków będących jej żywą pamięcią, jest rodziną rozbitą. Na-

${ }^{28}$ Maria Kaźmierczak, Mieczysław Plopa, Magdalena Błażek, „Rola więzi rodzinnych w rozwijaniu empatii”, w: Psychologia rodziny. Matżeństwo i rodzina wobec wspótczesnych wyzwań, red. Teresa Rostowska (Warszawa: Wydawnictwo Difin, 2009), 216-219.

${ }^{29}$ Franciszek, ,Solidarność między pokoleniami. Przesłanie z okazji 47. Tygodnia Społecznego Katolików Włoskich”, L`Osservatore Romano 11 (2013): 33. 
tomiast rodzina, która pamięta, jest rodziną, która ma przyszłość. Dlatego też „cywilizacja, w której nie ma miejsca dla osób starszych lub są one odrzucane, bo stwarzają problemy, jest nosicielem wirusa śmierci”, ponieważ „odrywa się od swoich korzeni”. Zjawisko współczesnego osierocenia, w zakresie braku ciągłości, wykorzenienia i upadku pewników kształtujących życie, wzywa nas, abyśmy czynili z naszych rodzin miejsce, w którym dzieci mogą się zakorzenić w glebie zbiorowej historii ${ }^{30}$.

Rodzina, stanowiąc podstawową komórkę społeczną, w sposób naturalny uczestniczy w życiu społecznym. Trwałe, dające poczucie bezpieczeństwa relacje rodzinne są nieodzowne dla rozwoju dziecka. W interakcjach z rodzicem, który odpowiada na szeroką gamę emocji, dziecko uczy się, że ekspresja emocji jest użyteczna w społecznych relacjach. Wzrastając w człowieczeństwie, coraz bardziej kształtuje swoją osobowość i uczy się stosunków naprawdę personalnych.

Bez zasad postępowania i życia, obowiązujących na co dzień, także w rzeczach błahych, charakter się nie kształtuje i nie jest się przygotowanym do stawienia czoła próbom, których nie zabraknie w przyszłości. Więź wychowawcza to przede wszystkim jednak spotkanie dwóch wolności, a dobrze wychować znaczy nauczyć właściwego korzystania z wolności. W miarę, jak dziecko rośnie, staje się nastolatkiem, później młodym człowiekiem; powinniśmy zatem godzić się na ryzyko wolności i być zawsze gotowi pomagać w korygowaniu błędnych idei i wyborów. To natomiast, czego nie powinniśmy robić nigdy, to nie reagować na błędy, udawać, że ich nie widzimy, czy gorzej, uczestniczyć w nich, jak gdyby były nowymi horyzontami postępu ludzkości ${ }^{31}$.

Osoba jest ostatecznym celem społeczności. Człowiek spełnia się wtedy, kiedy jest osobiście powołany do współtworzenia dobra wspólnego. Nie ma więzi społecznej bez tego pierwszego codziennego wymiaru, niemal mikroskopijnego: przebywanie razem w bliskości, mijając się ze sobą w różnych porach dnia, martwiąc się o to, co dotyka nas wszystkich, spiesząc sobie nawzajem z pomocą w małych codziennych sprawach.

${ }^{30}$ Franciszek, Adhortacja apostolska Amoris laetitia (19.03.2016) (Wrocław: Wydawnictwo Wrocławskiej Księgarni Archidiecezjalnej, 2016), 193.

31 Benedykt XVI, „List do diecezji rzymskiej o pilnej potrzebie wychowania”, L Osservatore Romano 4 (2008): 5. 
Głównym motywem jest poszukiwanie wartości egzystencjalnych oraz wewnętrznych, żywotnych dążeń do tego, co prawdziwe, dobre, piękne, sprawiedliwe, do życia bogatego w treść, refleksję, harmonijne relacje i porozumienie. (...) Rozwój to wzrost ludzi, zdolność myślenia, kultura, relacje międzyosobowe, a wreszcie organizacja społeczności na szczeblu globalnym ${ }^{32}$.

Pod wpływem nowych technologii cyfrowych ulegają zmianie podstawowe modele komunikacji i relacje międzyludzkie. Zmiany te są szczególnie widoczne wśród ludzi młodych, którzy wychowali się w ścisłym kontakcie z nowymi technikami komunikacji i dobrze się czują w cyfrowym świecie. Ten z kolei często wydaje się obcy dorosłym, którzy musieli uczyć się i doceniać, jakie możliwości komunikacji on stwarza. Pragnienie łączności i instynkt komunikowania się, tak oczywiste we współczesnej kulturze, w rzeczywistości są niczym innym jak nowoczesnym wyrazem podstawowej i stałej skłonności człowieka do przekraczania samego siebie, by nawiązać relację z innymi ludźmi. Kiedy bowiem otwieramy się na innych, zaspokajamy nasze najgłębsze potrzeby i osiągamy pełnię człowieczeństwa. Nowa przestrzeń cyfrowa pozwala spotkać się i poznawać wartości i tradycje innych. Byłoby rzeczą smutną, gdyby nasze pragnienie podtrzymywania i rozwijania przyjaźni online realizowało się kosztem rodziny, sąsiadów i tych wszystkich, których spotykamy na co dzień - w miejscu pracy, w szkole czy w wolnym czasie. Kiedy pragnienie wirtualnej łączności staje się obsesją, człowiek zaczyna się izolować, zrywając realne więzi społeczne ${ }^{33}$.

Dzisiaj - podkreśla papież Franciszek - gdy sieci i narzędzia komunikacji ludzkiej osiągnęły niesłychany rozwój, stajemy przed wyzwaniem, by odkryć i przekazać „mistykę” życia razem, wymieszania się, spotkania, wzięcia za rękę, uczestnictwa w tej nieco chaotycznej masie, która może zamienić się w prawdziwe doświadczenie braterstwa, w solidną karawanę, w święte pielgrzymowanie. W ten sposób większe możliwości komunikacji zmieniają się na większe możliwości spotkania i większą solidarność między wszystkimi. Gdybyśmy mogli iść tą drogą, byłoby to rzeczą tak dobrą, tak uzdrawiającą,

32 Appi, „Nowy humanizm”, 211.

33 Por. Benedykt XVI, „Nowe technologie, nowe relacje. Trzeba rozpowszechniać kulturę szacunku, dialogu i przyjaźni. Orędzie na XLIII Światowy Dzień Środków Społecznego Przekazu (24 stycznia 2009 r.)”, L’Osservatore Romano 3 (2009): 5-7. 
tak wyzwalającą, tak bardzo rodzącą nadzieję! Dobrze wyjść poza siebie, by przyłączyć się do innych ${ }^{34}$.

\section{Zakończenie}

Życie ludzkie nie jest tylko praktyczną egzystencją tu i teraz, lecz domaga się odpowiedzi w postaci określonego ustosunkowania się do świata. We współczesnej rzeczywistości głębokie zmiany w każdej dziedzinie wstrząsnęły podstawami życia osobistego i społecznego, prowadząc do zaniku istotnych pewników egzystencjalnych. Wychowanie jest autentyczne, czyli ukierunkowane na prawdziwe dobro podmiotów, kiedy pomaga im włączyć się w odpowiedni sposób w rzeczywistość.

Wychowanie osoby ludzkiej - jak stwierdza Katarzyna Olbrycht - jest wychowaniem do wartości, jakimi są w pierwszym rzędzie godność i powołanie człowieka. Powołaniem tym jest poszukiwanie prawdy, dążenie do odkrytego w prawdzie dobra, kontemplowanie piękna i tworzenie warunków do jego ujawniania się w świecie. Jest to powołanie do miłości jako bycia bezinteresownym darem dla drugiego. Wychowanie do wartości osobowych powinno uwzględniać w programach i ich realizacji zasadnicze etapy dojrzewania do wartości, ich przyswajania, dobrowolnego wybierania, wiernego realizowania ${ }^{35}$.

Aby młody człowiek otworzył się na to, co jest mu proponowane, trzeba, żeby został zaangażowany, a więc aby doświadczył takiego pragnienia i wyczuł możliwość, iż spełnienie leży w jego zasięgu. Obywatelstwo jest zespołem praw i obowiązków, a bycie obywatelami w społeczeństwie oznacza akceptację jego reguł. Różnoraka przynależność (rodzinna, terytorialna, klasowa, religijna, narodowa) nie jest przeszkodą, ale bogactwem.

Poglądy, style życia, prawa, cele, jakie sobie stawia społeczeństwo, w którym żyjemy, i obraz samego siebie, jaki daje ono za pośrednictwem środków przekazu, rzeczywiście wywierają wielki wpływ na kształtowanie nowych pokoleń, zarówno pozytywny, jak i negatywny. Społeczeństwo nie jest jednak abstrakcją; ostatecznie to my sami je tworzymy, wszyscy razem, wraz z orientacjami,

\footnotetext{
${ }^{34}$ Franciszek, Adhortacja apostolska Evangelii gaudium, 87.

${ }^{35}$ Katarzyna Olbrycht, „Wychowanie do wartości - w centrum aksjologicznych dylema-
} tów współczesnej edukacji”, Paedagogia Christiana 1/29 (2012): 100. 
zasadami i przedstawicielami, których sobie obieramy, jakkolwiek role i odpowiedzialność każdego są różne. Potrzebny jest zatem wkład każdego z nas, każdej osoby, rodziny czy grupy społecznej, ażeby społeczeństwo (...) stało się środowiskiem bardziej sprzyjającym wychowaniu ${ }^{36}$.

Wychowanie domaga się wspólnoty, wzajemnej pomocy, poczucia, że kroczy się razem. Komunikacja w wirtualnej przestrzeni może być znakiem autentycznego dążenia do osobowego spotkania z drugim człowiekiem. Kultura spotkania wymaga, byśmy byli gotowi nie tylko dawać, ale również przyjmować od innych, co pozwala wzrastać we wzajemnym zrozumieniu, szacunku i solidarności między wszystkimi.

\section{The Culture of Active Citizenship as the Reason of Social Life (Summary)}

In the course of the transformations that take place in life, events that become part of a human being, fit into the history of his life, and identify important areas of his activity and commitment. The diverse memberships (family, territorial, class, religious, national) are not an obstacle but an abundance. Citizenship is a set of rights and obligations, and being a citizen in society means accepting its rules. The true human community is where the person finds himself through the gift of himself and the ability to accept the gift of another person. The whole meaning of the so-called worldly human life then only gains value when all that a man does now is merely the beginning of the "fulfilment" and achievement of the human person in his personal file.

Keywords: person; culture; society; values; community.

\section{Kultura aktywnego obywatelstwa racją życia społecznego (Streszczenie)}

W toku przemian dokonujących się na przestrzeni życia zdarzenia, które stają się udziałem człowieka, wpisują się w historię jego życia, wyznaczają ważne obszary jego aktywności i zaangażowania. Różnoraka przynależność (rodzinna, terytorialna, klasowa, religijna, narodowa) nie jest przeszkodą, ale bogactwem. Oby-

${ }^{36}$ Benedykt XVI, „List do diecezji rzymskiej”, 5-6. 
watelstwo jest zespołem praw i obowiązków, a bycie obywatelami w społeczeństwie oznacza akceptację jego reguł. Prawdziwa wspólnota ludzka jest tam, gdzie osoba odnajduje siebie poprzez dar z siebie i zdolność przyjęcia daru drugiego człowieka. Cały sens tak zwanego doczesnego życia ludzkiego wtedy tylko zyskuje wartość, gdy to wszystko, co człowiek czyni teraz, jest tylko zapoczątkowaniem ,pełni” i spełnienia się ludzkiej osoby w jej aktach osobowych.

Słowa kluczowe: osoba; kultura; społeczeństwo; wartości; wspólnota.

\section{Bibliografia}

Appi, Franco. „Nowy humanizm a spójność Europy”. Społeczeństwo 1-2 (2015): 205-217.

Benedykt XVI. „List do diecezji rzymskiej o pilnej potrzebie wychowania”. L 'Osservatore Romano 4 (2008): 4-6.

Benedykt XVI. „Nowe technologie, nowe relacje. Trzeba rozpowszechniać kulturę szacunku, dialogu i przyjaźni. Orędzie na XLIII Światowy Dzień Środków Społecznego Przekazu (24 stycznia 2009 r.)”. L 'Osservatore Romano 3 (2009): $5-7$.

Benedykt XVI. „W obronie chrześcijańskiego dziedzictwa Europy. 30 III 2006 do uczestników kongresu zorganizowanego przez Europejską Partię Ludową”. L'Osservatore Romano 8 (2006): 19-20.

Bogunia-Borowska, Małgorzata. „Życie w dobrym społeczeństwie. Wartości jako fundament dobrego społeczeństwa”. W: Fundamenty dobrego społeczeństwa. Wartości, red. Małgorzata Bogunia-Borowska, 13-45. Kraków: Wydawnictwo Znak, 2015.

Cattaneo, Arturo. „Społeczna rola rodziny”. Społeczeństwo 3 (2014): 110-116.

Chrobak, Stanisław. „Człowiek twórcą/podmiotem rozwoju - wyzwania edukacyjne w globalizującym się społeczeństwie". W: Wychowanie i kształcenie w systemach politycznych, red. Elmar Anhalt, Dariusz Stępkowski, 151-164. Warszawa: Wydawnictwo Salezjańskie, 2012.

Chrobak, Stanisław. Podstawy pedagogiki nadziei. Współczesne konteksty w inspiracji personalistyczno-chrześcijańskiej. Warszawa: Wydawnictwo Uniwersytetu Kardynała Stefana Wyszyńskiego, 2009.

De Meo, Francesco. „Komunikacja w służbie nauki społecznej Kościoła”. Społeczeństwo 3 (2014): 72-83.

Desol, Chantal. Esej o człowieku późnej nowoczesności, tłum. M. Kowalska. Kraków: Wydawnictwo Znak, 2003. 
Flores d'Arcais, Giuseppe. „Propozycja personalistyczna”. W: Człowiek - Wychowanie - Kultura. Wybór tekstów, red. Franciszek Adamski, 80-95. Kraków: Wydawnictwo WAM, 1993.

Franciszek. Adhortacja apostolska Amoris laetitia (19.03.2016). Wrocław: Wydawnictwo Wrocławskiej Księgarni Archidiecezjalnej, 2016.

Franciszek. Adhortacja apostolska Evangelii gaudium (24.11.2013). Częstochowa: Edycja Świętego Pawła, 2013.

Franciszek. „Najcięższą chorobą, na jaką są narażone osoby starsze, jest opuszczenie. Przesłanie z okazji 20-lecia Papieskiej Akademii Pro Vita’. L 'Osservatore Romano 3-4 (2014): 20-21.

Franciszek. „Solidarność między pokoleniami. Przesłanie z okazji 47. Tygodnia Społecznego Katolików Włoskich”. L`Osservatore Romano 11 (2013): 32-34.

Galantino, Nunzio. „Wychowywać młodzież do odpowiedzialnego obywatelstwa”. Społeczeństwo 1-2 (2015): 172-176.

Heschel, Abraham Joshua. Prosiłem o cud. Antologia duchowej madrości, thum. Aleksander Gomola. Poznań: W drodze, 2001.

Jan Paweł II. Encyklika Redemptor hominis (Rzym, 4 marca 1979). Warszawa: Wydawnictwo Ośrodka Dokumentacji i Studiów Społecznych, 1979.

Jan Paweł II. List apostolski Novo millennio ineunte (06.01.2001). Warszawa: Centrum Duszpasterstwa Archidiecezji Warszawskiej, 2001.

Kaźmierczak, Maria, Mieczysław Plopa, Magdalena Błażek. „Rola więzi rodzinnych w rozwijaniu empatii”. W: Psychologia rodziny. Matżéstwo i rodzina wobec współczesnych wyzwań, red. Teresa Rostowska, 216-235. Warszawa Wydawnictwo Difin, 2009.

Krakowiak, Piotr. „Edukacyjne funkcje wolontariatu i ich percepcja w nauczaniu Kościoła w XXI wieku”. Paedagogia Christiana 2/32 (2013): 163-184.

Krąpiec, Mieczysław Albert. Człowiek w kulturze. Lublin: Redakcja Wydawnictw KUL, 1999.

Maritain, Jacques. Pisma filozoficzne, tłum. Janina Fenrychowa. Kraków: Społeczny Instytut Wydawniczy Znak, 1988.

Michalski, Jarosław. „Konstruowanie tożsamości podmiotowej w kontekście kategorii sensu w pedagogice". Paedagogia Christiana 2/32 (2013): 11-25.

Nowak, Marian. „Pedagogika wzorów i pedagogika spotkania w dialogu pokoleń”. W: Dialog pokoleń. Studium interdyscyplinarne, red. Kazimierz Franczak, 76-98. Warszawa: Wydawnictwo Salezjańskie, 2007.

Olbrycht, Katarzyna. „Wychowanie do wartości - w centrum aksjologicznych dylematów współczesnej edukacji”. Paedagogia Christiana 1/29 (2012): 89-104. Pezzotta, Savino. „Obecność katolików w polityce”. Społeczeństwo 5-6 (2013): $107-120$. 
Popielski, Kazimierz. „Pytanie o człowieka”. W: Człowiek-wartości-sens. Studia z psychologii egzystencji, red. Kazimierz Popielski, 15-21. Lublin: Redakcja Wydawnictw Katolickiego Uniwersytetu Lubelskiego, 1996.

Styczeń, Tadeusz. Rozum i wiara wobec pytania: Kim jestem? Lublin: Towarzystwo Naukowe Katolickiego Uniwersytetu Lubelskiego, 2001.

Sujak, Elżbieta. Rozważania o ludzkim rozwoju. Kraków: Wydawnictwo Znak, 1998. Tomaszewski, Tadeusz. Ślady $i$ wzorce. Warszawa: WSiP, 1984.

Wojtyła, Karol. „Osoba: podmiot i wspólnota”. W: tenże, Osoba i czyn oraz inne studia antropologiczne, 371-414. Lublin: Wydawnictwo Towarzystwa Naukowego KUL, 1994.

Zaborowski, Zbigniew. Problemy psychologii życia. Warszawa: Oficyna Wydawnicza PROFI, 2001. 
